\title{
The capability of national education systems to address ethnic diversity
}

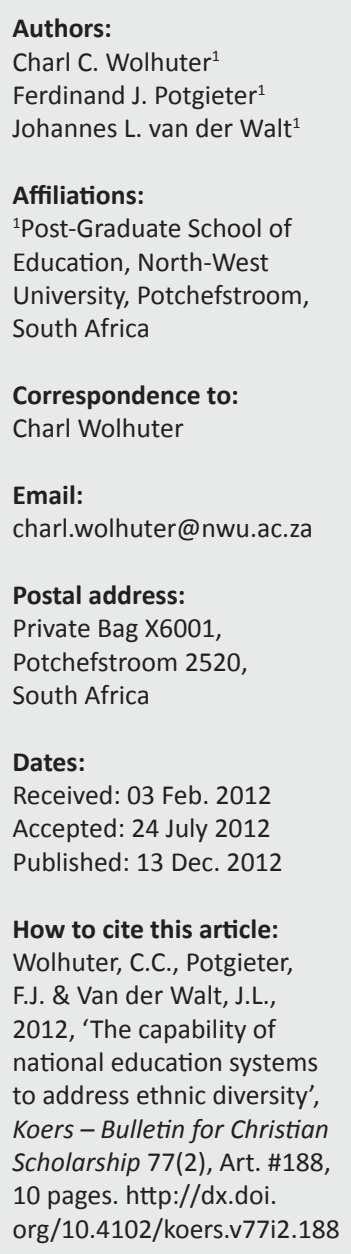

(C) 2012. The Authors. Licensee: AOSIS OpenJournals. This work is licensed under the Creative Commons Attribution License.
Modern societies have become much more complex in recent decades, also in terms of ethnic identities and differences. The question arose whether education systems were capable of addressing the needs of ethnic and other minorities in countries across the globe. After examining a cross-section of education systems (in Australia, Canada, China, Israel, Malaysia, Rwanda, Russia and South Africa) with the aid of a set of specially developed criteria, it was concluded that these systems seemed to comply with the criteria in various ways, albeit in different measures and in several configurations. It is recommended that policy makers apply such criteria for enhancing the capability of an education system to address the needs of ethnic minorities and to meet the demands of increased social complexity.

Die vermoë van nasionale onderwysstelsels om etniese diversiteit te akkommodeer. Samelewings het onlangs toenemend kompleks begin raak, ook in terme van etniese identiteite en verskille. Die vraag is of onderwysstelsels van lande reg oor die wêreld in staat is om te voldoen aan die eise van die verskillende etniese en ander minderhede. Na bestudering van 'n steekproef onderwysstelsels (dié van Australië, Kanada, Sjina, Israel, Maleisië, Rwanda, Rusland en Suid-Afrika) aan die hand van 'n stel spesiaal ontwerpte kriteria is tot die slotsom gekom dat hierdie stelsels oor die algemeen aan die kriteria voldoen, dog in wisselende mate en in allerlei konfigurasies. Dit is aanbeveel dat beleidmakers kriteria soos hierdie toepas ten einde toe te sien dat 'n onderwysstelsel inderdaad in staat sal wees om te kan voorsien in die behoeftes van etniese minderhede en aan die eise van toenemende sosiale kompleksiteit.

\section{Background}

Life in modern societies have recently become more complex, not only because of development in general, but also because of the greater social mobility of people because of political circumstances (asylum-seeking political refugees), tourism (prolonged visits to foreign countries because of greater wealth), displacement (due to xenophobia and natural disasters) and changes in socioeconomic status. The complexity has been compounded by a greater awareness of individual and group differences as well as ethnic identities with a concomitant insistence that such differences be accommodated in education systems (e.g. the Flemish in Belgium, certain groups in Somaliland, Basques in Spain, Afrikaners and Khoi-San in South Africa, the Darfur region in the Sudan, now South Sudan). The term 'ethnicity' is used in this article to refer to a group of people with a sense of a socio-conventional commonality. Recent events in many parts of the world, such as Sudan, Israel, Nigeria, France, the Balkan states and South Africa, show that ethnicity remains a reality that cannot be ignored. This is the rationale for the research reported below. An internet search will reveal the presence of minority groups and indigenous peoples in virtually every country of the world. Modern education systems therefore have to take into account several criteria when providing for the needs of the ethnic communities they serve. As far as we could determine, no such criteria have been systematically developed for gauging whether an education system has been complying efficiently with the demands of increasingly complex societies. This article reports on research in this respect.

After applying the criteria for accommodating ethnic diversity to a sample of national education systems, we concluded that educational systems tend to comply with the criteria in different measures and in a variety of configurations. The purpose of this article is to defend this contention. In order to do this, we firstly outline the critical-interpretive-constructivist methodology used for developing a set of criteria with which we could approach the education systems. We then apply these criteria to a sample of education systems, with special reference to the accommodation of ethnic diversity. The article concludes with a recommendation regarding the accommodation of ethnicity. 


\section{Research method}

In order to construct criteria that could be utilised for exploring and interpreting the extent to which education systems across the globe are capable of addressing the needs of ethnic minorities, we needed to establish what may be regarded as the critical elements of such criteria. Our first inclination was to developa set of criteria founded on Biblical perspectives such as recognition of the uniqueness of individuals and groups, a notion based on the worth and dignity of the human being as Imago Dei. However, our investigations brought to light that we could develop a set of universal criteria that would be justifiable from a Biblical perspective as well. Put differently, the criteria that we present below in the conceptual-philosophical-theoretical framework have been found to apply universally and to be justifiable based on pertinent Biblical principles (see Pratt [2000] for a Biblical perspective). It can therefore be said that our approach was rooted in Functionalism as underlying philosophy. Functionalists (in our case, functionalists mindful of Biblical directives) believe that education systems should serve society as a whole, should strive for social good, cohesion, generosity and harmony, comfort people and attempt to make society collectively stronger (Wright 2009:44, 63-66).

In line with our functionalism, we followed a cross-over, hybrid methodological approach that may be termed critical-interpretive-constructivist. This approach was based on Jansen's framework for critical theory and the work of Caldwell (2003), Cohen (1970), Cowan, O'Connell and Scanlon (1965), Thompson (1981), Waghid (2007) and Welch (1991). It provided us with the coordinates for the criterion unity, commonality, communality and national unity. For the criterion of individual and group differences we turned to Potgieter and Van der Walt (2008) and Sherman Swing (2010). The work of Giddens (1994), Nieuwenhuis (2010) and Van Deventer (2010) clarified the criterion of social justice, while the epistemologies provided by Armesto (2004), Du Preez (2009), Jackson and Jackson (2008), Karvelas (2006), Soodyall (2006), Van Beek (2006), Van der Walt (2010) and Wielemans (1993) helped us to formulate the criterion of anthropological equivalence and human rights. The work of Basave (2006), Jansen (2009), Krüger and Helsper (2006), Lucas (1984) and Reid $(1999,2006)$ provided the theoretical guideposts for the criterion of pedagogical demands. Finally, to address issues of equality, we turned to the principles provided by the work of Berkhout and Bondesio (1987), Bowie (1970), CambronMcCabe and McCarthy (2004) and Mncwabe (1990).

This methodological stance enabled us to develop six criteria for analysing and evaluating the capability of national education systems to provide in and for the needs of ethnic and other minorities. By applying these criteria, we were able to determine the extent to which an education system (and by implication the policy makers behind the system) was capable of providing in the said needs. We regarded adherence to the criteria as indicative of the measure to which the particular system was able to accommodate the various needs, with particular reference to ethnic diversity, within its national boundaries.

The following conceptual-philosophical/life and worldviewtheoretical framework consists of a brief outline of each of the criteria.

\section{Conceptual-philosophical- theoretical framework Recognition of individual and group differences}

The semantic shift in education since the 1980s or so in scholarly debates from the notion of multicultural education to that of diversity, difference and nowadays to sameness, brings to the fore the old debate regarding the recognition of individual and group differences in and by national education systems. The nature and content of these debates are as difficult and contested as ever. Although most scholars may agree that learners are active architects of meaning and that the knowledge and identities that they manage to acquire and assemble at school (and elsewhere) essentially constitute social constructs (Potgieter \& Van der Walt 2008:44), they may not necessarily agree about, for example, identity as a marker of individual and/or group difference (Sherman Swing 2010:87-98).

A person's identity can only exist in community with other people, according to Rorty. He claims that when we are isolated, we lose ourselves. The irony is, however, that as community and sameness are emphasised, togetherness can be lost. As we lose our idea of self, we lose our concept of common humanity, of that which unites us, and we are segregated into our own little communities. Consequently, our ability to have meaningful engagement with those from other communities is lost and group differences - rather than what we share in common as people, that is, our sameness become what defines us (Potgieter \& Van der Walt 2008:44).

In counterpoint to Danieli's view that an individual's identity involves a complex interplay of multiple spheres or systems, Jansen $(2009: 79,107)$ warns that if an education system were to allow for ethnicity as a socially dividing construct in its curricular endeavours, chances are that the learners in such a system will only learn about ethnic differences in terms of racial, ethnic and cultural exclusiveness, in the process reproducing social inequality, thereby further dividing the social fabric. Even semantically more elegant references to differences than the terms race and ethnicity (such as culture, language and group identity) can conceal derogatory and discriminatory meanings. This begs the moral question how a country's education system can prepare dialogicpedagogical spaces for its stakeholders and role-players to teach about difference if that country has never had a national conversation about sameness.

The discourse on multicultural education has, since the inception of this term more than thirty years ago, progressed through a number of phases (cf. Wolhuter 2012:178). In the first 
phase other cultures were presented in curricula and school organisation as interesting and token accessories or 'addons' to the dominant culture. Out of concern for xenophobic attacks and intercultural conflict, multicultural education then became intertwined with anti-racist education. In a third phase, amidst the increasing emphasis which specialist fields of Education such as Sociology of Education have placed on power-relations in society, multicultural education progressively took on the form of anti-oppressive education. In the most recent phase, after the events of $9 / 11$ and in an age of globalisation, multicultural education coagulated in the form of intercultural education, which contains elements of all the previous phases, as well as elements of critical and reflexive multiculturalism. The four basic principles of intercultural education can be enunciated as follows:

1. education with empathy, that is, deep understanding of the other

2. education in solidarity, meaning that an appeal is made to the cultivation of a collective human conscience and social justice

3. education in and for intercultural respect

4. education for ethnic thought and dialogue (Wolhuter 2012:178).

This article and the development of criteria are premised on the school of thought of intercultural education.

\section{Recognition of unity, commonality and communality (national unity, nation building)}

Viewed historically, the school has always been exploited for reaching the objectives of other, more dominant societal institutions (e.g. the state, industry, wider community). National education systems were created by states to serve their own interests. One of these interests was to legitimise the existence of the state and to create a sense of nationhood, that is, the forging of national unity (Cowan, O'Connell \& Scanlon 1965, Cohen 1970, Thompson 1981, Welch 1991). We realised that we could not use the past as a norm for the school as a societal relationship, and therefore looked for a norm that would transcend past and present practices by states and other institutions of dominating the school as a societal relationship, thereby negating the notion of the school as an independent societal relationship or institution in its own right. According to this sovereignty principle, the school as a societal relationship exists independently alongside the state (as a sovereign societal relationship) and other societal relationships (e.g. family, church, community, business, etc.) According to the universality principle, they are interlinked, composed of the same persons and intent on caring for one another's interests. Based on this sovereignty-universality principle, the education system, in general, and schools, in particular, should seek to promote unity, commonality, communality, nation building and national unity. School and state should not be viewed as competitors; instead, schools should see themselves as institutions where good 'citizens' of the state are educated (Caldwell 2003:4; Waghid 2007: passim) and as such, promote the interests of the state, also in terms of contributing to national unity and its concomitant national interests.

\section{Recognition of social justice}

Justice forms the nucleus of the concept 'social justice' (Van Deventer 2010:5). Although one of the key features of a modern human society is the notion of justice as a legal construct that is morally right, fair and efficient (Van Deventer 2010:6), social justice, per se, is not an external condition or system (Nieuwenhuis 2010:1). Instead, it is an ideal that should become a way of life that permeates all aspects of being human.

Available evidence suggests that social justice is a social and cultural phenomenon that embraces and embodies, amongst others, the common good. It is, however, also a political, democratic, human right and educational phenomenon (Van Deventer 2010:5) and, as such, it requires that every citizen should take responsibility to protect, advance and promote the shared values and ideals (Nieuwenhuis 2010:2) that underpin social justice praxis. Theoretical formulations of social justice, such as commutative justice, distributive justice, retributive justice, contributive justice and prospective justice (Van Deventer 2010:5; Nieuwenhuis 2010:3) mark the parameters of the social as well as the legal space in which such social justice praxis may be realised.

This notion of social justice is central to the work of Giddens (1994). He sees social justice (amongst others) as a space that allows for repairs to be done to damaged solidarities and for making things happen (Nieuwenhuis 2010:6, 7), a space where a democracy can be created in which all issues may be debated openly and honestly. The reality is that the policies and practices of the dominant social group in any country usually result in social justice being defined according to economic gain, while marginal themes tend to focus more on the development of social cohesion and a sense of community.

The fact is that social justice essentially remains embedded in a struggle for social change, particularly against domination and oppression of varying kinds (Nieuwenhuis 2010:7, 9).

\section{Recognition of anthropological equivalence and basic human rights}

Most modern societies acknowledge the fact that all their citizens are in principle equal, and that no one has the right to discriminate against any other person on the grounds of an individual or group difference (Armesto 2004:264-265; also see the Children's Charter of South Africa, International Children's Summit 1992 and the UN's Universal Declaration of Human Rights 1948). Human rights are based on the premise that all people, regardless of their nationality, background, history, culture, religion, language, ethnicity, colour, ability or gender, ought to have certain basic freedoms, rights and privileges.

According to some theorists, individuals and groups have both positive and negative rights. Positive rights are rights that provide freedom to obtain something such as the right to education, employment, welfare, and hospital care. Negative rights imply freedom from oppression by (for instance) the 
Government: the right to freedom of expression, movement, assembly, press, religion, a fair trial, and so on (Karvelas 2006:passim; Jackson \& Jackson 2008:484-485).

Whilst differentiation on the grounds of certain differences can be justified (such as different bathrooms for the two genders; different schools and classes for learners with, for example, severe impediments; different media of instruction for learners belonging to different language communities or schools in different regions), differentiation on certain other grounds can be construed as discriminatory (such as separate schools for different race or colour groups, ethnic groups or socio-economic statuses). Circumstances may dictate whether differentiation would be justifiable or not, such as: ethnic and group-related social conventions, historical background and religious and life-view commitments. Some of the terms referring to anthropological differences, such as race, have become obsolete and should be avoided (Du Preez 2009:38,75), whereas others merely refer to the contingencies of a person's birth, such as skin colour variations (Soodyall 2006:160), and therefore need not be accommodated in an education system. In fact, as Van Beek (2006:372) argues, fixation on a contingency can lead to undesirable attitudes and actions. A fixation on ethnicity, for instance, can lead to xenophobia or forms of neo-apartheid (ethnic and race segregation). Despite these threats, ethnic (minority) groups in countries all over the world have in the past shown a tendency towards insisting that special provision be made for them and their particular needs. We cannot close our eyes to this de facto demand from some ethnic groups.

Since it is not possible to formulate an unambiguous criterion for the accommodation of individual and group differences in an education system, one can - at the very least - expect of an education system to be sensitive about any individual and group differences in the citizenry, in this case ethnic differences, to provide in and for the needs of each ethnic group as expressed by a group itself (not imposed on it through legislation, for instance), and to avoid and combat any form of discrimination (based on ethnicity, in this case) that might crop up in the populace. In many countries, the equality and equivalence of each and every citizen finds expression in a bill of fundamental human rights (Wielemans 1993:7). The education system of a country should not only respect these fundamental rights and freedoms of the citizens, but should also be actively aimed at promoting their rights and freedoms, as well as those of ethnic groups that demand recognition. The same applies to the relationships in which each individual is involved. According to Wielemans (1993:8), the individual can only be understood in relation to others, also in terms of ethnic bonds, if so desired by the individual. This sentiment resonates in current scholarly work that distinguishes between the other and an other (Jansen 2009). The former refers to a person from a (presumed) different ethnic or cultural background, while the latter refers to the recognition (by the observer) of anthropological sameness. Each individual is also an intersection of relationships. This sentiment is echoed in the revised version of $u b u n t u$ propagated by Van der Walt (2010:237-239).

\section{Recognition of pedagogical demands}

An education system finds its raison d'être [its purpose] in the fact that it is pedagogically qualified, in other words a system aiming at forming and socialising young(er) citizens towards greater levels of maturity. The classical Greek ideal of paideia (Krüger \& Helsper 2006:67) is helpful here since it refers to the ideal of issuing a 'cultured individual', one who participates in and shares a literate culture, the state of being fully human and sharing human characteristics to the fullest possible extent (Lucas 1984:128). According to Basave (2006:72), education for paideia is the process of developing an imperfect human being intentionally towards reaching the ideal of human plenitude in the best possible manner. As a method, it means intentionally guiding a human being towards the plenitude of the harmonious formation of man. Personalised education does not exclude that which is essential - common and equal - in all human beings; instead, it invigorates and justifies the individual himself and his or her individual personality.

What should be uppermost in the mind of the person in charge of the entire education system of a particular country? What should he or she aspire to? The replies of the DirectorGeneral of a system and/or the Minister of Education of a particular country to questions such as the following would be indicative of whether they have sound understandings of their task: is the system aimed and geared at providing optimal opportunities for all learners - irrespective of ethnic background and affiliations - to attain maximum achievement and excellence, at forming each and every learner to paideia in the most complete sense of the word, at helping as many as possible of the learners to contribute to the welfare of all the communities concerned as well as to that of the entire nation? Since these questions reflect both meanings of education (teaching-learning as well as forming), the answers provided by the officials should also do so. Not only should the students as learners be able to achieve at the highest academic levels; they should also, as educands, be guided to attain the highest levels of paideia, and in both capacities be able to contribute to the welfare of their communities and the entire nation.

\section{Recognition of equality}

Since the middle of the twentieth century one of the most important drivers behind the expansion of educationprovision worldwide has been equality and equal educational opportunities (Wolhuter 1993:passim). Equality is one of the most elusive concepts in the social sciences (Bowie 1970:xv) and discussions about equality have been known for their ambiguity (Mncwabe 1990:27). After a literature survey Wolhuter (1993:77) came to the conclusion that it is possible to distinguish between a number of conceptualisations of equal educational opportunities. As indicated in Table 1 below, these can be arranged on a continuum from emphasis on the individual to emphasis on society. Berkhout and Bondesio add to this continuum in their 1987 paper by distinguishing between two broad categories of conceptualisations of equal educational opportunities, namely 'individual-liberalist' 
approaches that is, (1) every individual gets full opportunity to realise his or her potential, (2) equal access and (3) equal input), and 'social-reform' approaches, (4) equal progress, (5) equal survival, (6) equal certification and (7) equal effect.

After having looked at the above-mentioned views about equal educational opportunities, we align ourselves with the view of Cambron-McCabe and McCarthy (2004:89) that policies and procedures within an education system should, above all, be equitable, fair, effective, and adequately protect all learners' educational rights.

\section{Evaluation of education systems against the above criteria}

We selected a cross-section of eight education systems across the world. We regarded the sample, consisting of Australia, Canada, China, Israel, Malaysia, Rwanda, Russia and South Africa, as representative of the situation world-wide in terms of geography as well as different developmental levels (low, medium as well as high income). Some are countries that have enjoyed a relatively peaceful recent history (Australia and Canada), others are countries whose recent history has been characterised by low-intensity interethnic conflict (Malaysia, Russia and South Africa), whilst two are examples of countries that suffered a recent history of violent interethnic conflict (Israel and Rwanda).

\section{Australia}

Despite the fact that since the 1980s the Australian system has been based on a policy of multiculturalism (O'Neill 2010: 48-50), there has been a recent shift towards greater national cohesion in line with the tenets of the neo-liberal economic revolution: the prime function of an education system is to supply the economy with a pool of schooled human resources. This is a shift in the direction of national unity and nation building (our criterion number 2). A glance at Australia's past shows that since the founding of the state in 1901 this has not always been the case. As far as the indigenous population was concerned, policy stipulated until 1967 that the respective federal states would provide formal education to Aborigine children, but that White parents could demand the exclusion of such children from public schools (Tomlinson 2008). This exclusion, coupled with the policy of assimilating the Aborigines in the dominant White culture (cf. Stanner 1969), can be regarded as non-compliance with our social justice criterion (number 3 ). This policy also did not comply with the demand for anthropological equivalence and respect for human rights (criterion number 4). It is also doubtful whether such a policy can be construed as respect for individual and group differences (criterion number 1) and equality (criterion number 6). If differences were respected and the indigenous inhabitants of the land were seen as equal to all other people, why should they disappear as a group and be assimilated by the dominant group? According to O'Neill (2010:35), the education received by the children of the indigenous people was of inferior quality; whatever education they received was intended to train them as cowherds and housemaids. Such an approach contravenes our equality and fairness criterion (criterion number 6).

In 1967, the responsibility for Aborigine education was transferred from the federal states to the central government. The government followed a new policy of self-determination and autonomy of decentralised Aborigine communities (O'Neill 2010:36). Although the new policy amounted to a system of 'two-way schooling' for the Aborigines (traditional education combined with Western elements), very little success was attained with it since it mostly depended on the enthusiasm of individuals (Australian Institute of Aboriginal and Torres Strait Islander Studies (AIATSIS) \& Federation of Aboriginal and Torres Strait Islander Languages (FATSIL) 2005). Some of the initiatives were fairly successful, for instance the Fitzroy Valley Community self-help plan and the Follow the Dream program in Western Australia (O'Neill 2010:38). Despite the laudability of these efforts, they do not seem to be in consonance with our criteria regarding the recognition of individual and group rights (criterion number 4), the pedagogical needs of a minority group (criterion number 5), and fair and equitable treatment (criterion number 6).

Whereas the Aborigine community represents only three percent of the total population, one out of every four of the 22 million Australian people were born outside of the country, and one out of every two has at least one parent born elsewhere. In the case of immigrants, a policy of multiculturalism has been followed since the 1970s and 1980s. The current position, as explained by the Ministry of Immigration, is that the acquisition of Australian citizenship does not demand the suppression of immigrants' cultural heritage or identity. On the contrary, they contribute their languages, cultures and traditions towards the enrichment of Australian culture (O'Neill 2010:42). As a result of this policy, Modern Greek was introduced as a subject in primary schools in Victoria, and Greek-born Australian teachers are being trained at the University of Crete (Chipman 1980). This immigration policy does not seem to comply with our notion of commonality and thus of nation building and the promotion of national unity (criterion number 2). It does, however, meet the pedagogical requirements of (in this case) the Greek community in Victoria (criterion number 5).

\section{Canada}

After the establishment of the Canadian Federation through the British North American Act of 1867 education of Canada's

TABLE 1: Continuum of views on equal educational opportunities.

\begin{tabular}{lll}
\hline Views & \multicolumn{2}{c}{ Approaches } \\
\cline { 2 - 3 } & Individual-liberal (Individual) & Social-reform approaches (Society) \\
\hline $\begin{array}{l}\text { Equal educational } \\
\text { opportunities }\end{array}$ & Opportunity for every individual to realise his or her potential & $\begin{array}{l}\text { Statistically, all societal categories attain the same, equal rate of progress } \\
\text { or survival } \\
\end{array}$ \\
& $\begin{array}{l}\text { Every individual receives equal access } \\
\text { Every individual receives equal input }\end{array}$ & $\begin{array}{l}\text { Statistically, all societal categories attain the same, equal standard of life, } \\
\text { income and livelihood }\end{array}$ \\
\hline
\end{tabular}


indigenous communities was seen as the responsibility of the federal government (Isaac 1995:170). The federal government administrated education in accordance with the Indian Act of 1876. Policy at that time not only kept the indigenous population separate from the Europeans but also did not recognise the diversity within the Indian population itself (Ottmann 2010:62). This does not seem to be in consonance with several of our criteria: recognition of individual and group differences (criterion number 1), national unity and nation building (criterion number 2), social justice (criterion number 3), anthropological equivalence and recognition of human rights (criterion number 4), fairness and equality (criterion number 6). Another of our criteria was not complied with in that the government in 1911 began providing compulsory education for Indian children between the ages of seven and fifteen in so-called residential schools in low-density areas. The Indian population rejected this policy since they thought that it robbed them of their culture, and took the education of their children out of their hands. The purpose of the schools was to Christianise and civilise the indigenous population and to assimilate them into the Anglo-Saxon culture (Ottmann 2010:63). This strategy does not comply with our criterion of meeting the pedagogical demands of a community, and not imposing unpopular policies on it (criterion number 5). The students in the residential schools were furthermore not allowed to use their home languages or to practise their own spirituality (Indian Residential Schools Survivor's Society 2009). By the time these schools were closed in 1996, some 15000 Indian children had reluctantly passed through them.

The situation began changing from 1972 onwards. In a White Paper entitled Indian control of Indian education it was declared that the First Nations would henceforth control the education of their children. The new approach was aimed at achieving two goals, namely the reinforcement of children's First Nations identity and to teach the skills required for making a successful living in a modern society. Although the separateness of First Nation education in their own schools can be questioned, it has to be kept in mind that the new approach was requested by the First Nations. This, in our opinion, conforms to the criterion of acknowledging the pedagogical demands of a group (criterion number 5). The decision of the First Nations to educate their children in their own, separate schools seems to have been vindicated by history. Since the introduction of the policy, their schools have increased from zero to 500 in 2008; 33000 First Nation students are currently involved in tertiary education, 4000 students graduate annually, and more than $80 \%$ have declared that they attach value to speaking their indigenous languages (Ottmann 2010:75-76). This is evidence of the recognition of individual and group differences (criterion number 1), of social justice (criterion number 3), of anthropological equivalence and human rights (criterion number 4), of meeting the pedagogical demands of the inhabitants (criterion number 5) and of equitable and fair treatment (criterion number 6). It is not clear to what extent this policy has contributed to significant national unity and nation building (criterion number 2).

\section{People's Republic of China}

The mainland Chinese population is composed of the Han majority (approximately $91.5 \%$ of the population) and 55 ethnic minorities (a total of more than 104 million people). The minorities typically live in less densely populated, autonomous areas. Although a relatively small group in terms of the entire population, minorities such as those in Tibet play a significant role in the maintenance of national and international stability (Yang \& Wu 2010:81). The minorities not only live in peripheral areas but are economically and socially under-developed; some of them have until recently been slave communities. This is proof of non-compliance in terms of fairness (criterion number 6) and human rights (criterion number 4) criteria. There were no formal schools in these areas prior to the 1950s. Less than one percent of the children of these communities attended primary, secondary and tertiary education institutions (Yang \& Wu 2010:81). The treatment of the minorities prior to 1950 was not consonant with all the criteria that we propounded: whereas their individual and group differences were recognised to some extent (criterion number 1), the minorities were not seen as part of the nation (criterion number 2), neither did they enjoy the fruits of social justice (criterion number 3), of equivalence and human rights (criterion number 4 ) and of equitable and fair treatment (criterion number 6), and their pedagogical demands were not met (criterion number 5).

Their conditions improved after the inauguration of the People's Republic of China in 1949. Efforts were made to uplift the minorities, and in some cases affirmative action was taken. They received preferential treatment in terms of the erection of educational institutions, lower school fees, hostels and remedial programs (Saltman 1999). Special [Kangend] schools were established in the mountainous areas, text books in the indigenous languages were supplied, and teachers were trained for working in the minority communities. Twenty universities for ethnic minorities and up to the present time more than 100 normal schools (i.e. teacher education institutions for minorities) have already been erected (Yang \& Wu 2010:87). Although the numbers of ethnic majorities have grown to $9.7 \%, 7.7 \%$ and $5.7 \%$ in primary, secondary and tertiary institutions respectively (Ministry of Education, People's Republic of China 2005), they do not as yet reflect the demographic profile of the country. Schools attended by children of the Han majority still reflect the sentiments and culture of that community (Postiglione 1999). The atheistic or anti-religious state schools also do not reflect the religions of the minorities attending those schools (Yang \& $\mathrm{Wu}$ 2010:89). Only the languages spoken by the majority group seem to receive attention. Concern has been expressed about the fact that the new policy has led to school segregation (Postiglione 1999). Although concerns can be raised about nation building and national unity (criterion number 2), the current policy in China seems to conform to most of the other criteria: it acknowledges group differences (criterion number 1), the policy can be regarded as socially just (criterion number 2), it respects the equivalence and the human rights of all (criterion number 3), it meets the pedagogical demands of all concerned (criterion number 4), and the treatment of all groups seems to be equitable and fair (criterion number 6).

\section{Israel}

The Israeli state consisted of immigrants from all over the world when it was established in 1948. The ethno-national 
norm of the country was, however, established and dominated by Ashkenazi Jews, that is, Jews who had emigrated from Europe (Bekerman 2010:102). This led to the marginalisation of minority groups in the country, including the orthodox Jews and Palestinians who had been living in the territory before the establishment of the Israeli state. The situation was exacerbated by the fact that all the minorities were seriously impoverished, and that they lived in separate communities. As a result of all their disadvantages their children's chances of passing final school examinations were small (Ministry of Education, Israel 2000). The initial treatment of ethnic minorities was not compliant with our criteria concerning the recognition of group differences (criterion number 1), the ideal of national unity (criterion number 2), of social justice (criterion number 3), of basic human rights (criterion number 4), of meeting the educational needs of minorities (criterion number 5) and of fairness and equitable treatment (criterion number 6).

The problem was exacerbated by the introduction of Hebrew as the official language, which was not the language of the immigrants, most of whom spoke English, German or French. The government launched a Hebrew literacy campaign in 1949, and by 1992 more than $77 \%$ of the immigrants declared that they had accepted Hebrew as first language (Bekerman 2010:107). Since Hebrew had become the chief instrument in the process of homogenising the population and for nation building, the Palestinian minority population found themselves excluded from tertiary study since Arabic is not offered as medium of instruction at universities. Although this strategy can be seen as a form of nation building (criterion number 2), it can also be construed as discriminatory against minorities (criterion number 6).

School curricula also only minimally reflect the requirements and perspectives of the various minority groups, including those of the Palestinians or Arabs (Bekerman 2010:103). No efforts were made to introduce the Jewish children to the Palestinian narrative (Al-Haj 2002), and curricula still seem to reflect only the traditions and perspectives of the Ashkenazi Jews at the expense of the Jewish minorities (Dahan \& Levy 2000). This is also not in compliance with the criteria of human rights (criterion number 4) and fairness (criterion number 6).

In the 1990s, a system of multicultural education was introduced, evidence of a more open and tolerant atmosphere. Recognition is now being given to the cultural heritage and history of the Mizrachi or Sephardim minorities. Dual-medium, integrated schools were also established for accommodating the children of immigrants from Russia (Resnick 2006; Bekerman 2004, 2005) despite the fact that the government was not in favour of it (Bekerman 2010:109). This current strategy seems to conform to all six of our criteria.

\section{Malaysia}

The population of Malaysia consists of three ethnic groups (Malays, Indians and Chinese). Because of historical circumstances the Indians and the Chinese came to belong to the higher classes in society and the Malays to the poorest. At the time of independence, the Malays represented only $55 \%$ of the population, but this percentage has now grown to some 65\% (Loo 2010:124). Affirmative action policies were introduced after independence to uplift the Malaysian population (Loo 2008:463, 485). This policy was also enforced in the education system.

Regarding language medium, provision was made for Malay, Tamil and Mandarin as well as English in the urban areas. Before independence, the latter played an important nation building role in the schools attended by children from all three ethnic groups. After independence, English was abolished as medium of instruction, and by 1985, Tamil was abolished in all schools and Mandarin in secondary schools. Only Malaymedium schools as well as a few Mandarin-medium primary schools remained (Loo 2008:480). The Chinese community's request to establish and fund their own Mandarin-medium university was rejected by government. This does not seem to comply with our criterion regarding the recognition of the needs of minorities (criterion number 1) and of basic human rights (criterion number 4).

The Chinese and Indian communities also feel discriminated against in terms of their religions. The national ideology of Rukunegara that has strong Islamic religious and Malay overtones and undertones pervades the entire school curriculum (Loo 2010:129-130). Sporadic violent resistance to government policies attests to the fact that the official line taken by government has not been successful (Loo 2010:134). Government's failure to recognise the rights of minority groups does not comply with our criterion number four.

\section{Rwanda}

Rwanda is inhabited by the Tutsi and the Hutu, of which the latter is the largest group. Traditionally, the Tutsi are cattle farmers whereas the Hutu tend to be agriculturalists. After the genocide of 1994, the Tutsi's numbers were reduced from approximately $15 \%$ to $10 \%$ of the population. Under colonialism, the Belgians preferred to employ members of the Tutsi community as public servants (Nzabalirwa 2010:141). The new government overturned this policy after independence in 1962 by favouring the Hutu both in the administration and in terms of schooling (Nzabalirwa 2010:145). Relations between the two groups deteriorated, resulting in the extermination of approximately 800000 Tutsi in 1994 (Dowden 2009:235). Rwanda's history is rife with examples of discrimination and a lack of fair treatment (criterion number 4 and criterion number 6).

After a period of violence, a new government took office in 2003; a new constitution was promulgated in terms of which discrimination was prohibited, especially on the grounds of ethnicity and religion. Hutu and Tutsi identities were also not allowed to play a role in the public and political arena. The new government placed itself on the side of peace and tolerance, and promised to follow a policy of 
non-discrimination and non-segregation. Schooling and examinations were to be conducted on the principles of equity and transparency (Nzabalirwa 2010:150-151). The new policies have been quite effective as can be seen from the fact that between 2000 and 2010 the per capita income has tripled, and the fact that the country is experiencing a period of relative peace and tolerance. In our opinion, the current policies in Rwanda comply with all our criteria, except the recognition of the ethnic group identities of the Hutu and Tutsi (criterion number 1).

\section{Russia}

Moscow and its immediate surrounds form the historic epicentre of Russia. By the 17th century, Russia had expanded eastwards and included Siberia, a region populated by several ethnic minorities, each with its own language (Pipes 1972:111). These minorities were soon assimilated into the Russian state, a process characterised by the imposition of a single alphabet, a national literature, theatres and museums (Savinov \& Kovaleva 2010:157). After 1917, this domination was taken further by Soviet Russia, finally resulting in the virtual disappearance of the Siberian languages and cultures. Various minorities are nevertheless still living in Siberia, together with some Caucasians who had moved eastwards as part of the Russian expansion. Since the 1990s, these minorities have been joined by immigrant groups from central and south-east Asia, especially China. This has compounded an already difficult situation in Siberia as far as the accommodation of minorities is concerned.

Post-Soviet Russia has been following a policy of equal rights to all citizens and non-discrimination on the grounds of differences among individuals and groups (Savinov \& Kovaleva 2010:162). It is not yet clear to what extent the new policy will bear fruit, especially in view of the economic difficulties in which the Russian Federation is finding itself. Whereas most of the policies of Soviet Russia did not comply with any of our criteria, those of present-day Russia seem to comply to a considerable degree.

\section{Republic of South Africa}

The Gini Index of South Africa (57.8), the fourth highest in the world, attests to the fact that not only does its population consist of a large number of minority groups but also that it is one of the most socio-economically unequal communities in the world (World Bank 2008). South Africa is well-known for the apartheid policies that were in force between 1948 and 1994 and which led to a segregated and unequal education system. After 1994, a new system was adopted based on desegregation, equal opportunities and multiculturalism (Wolhuter 1999). The desegregation process has been taking the form of a migration of Black learners from the disadvantaged township schools to the previously White schools. To a certain extent, racial segregation has been replaced by socio-economic segregation (Pape 1998). Apart from the fact that multiculturalism as a strategy has been discredited in some circles, government has been struggling since 1994 to provide education that would lead to the equal and equitable treatment of all the learners and also reflect African natural and cultural heritage in the school curriculum. Similar difficulties have been experienced in developing all eleven official languages as media of instruction in schools (Shiraya 2008:21). The policy on religion in schools promulgated in 2003 effectively banned all forms of confessional religion from schools.

Whereas practically all the education policies prior to 1994 were not consonant with our criteria, the situation has since been effectively turned around. The education system of South Africa now seems to comply with all the criteria, with the exception of criterion number one, in the sense that it still refuses to meet the pedagogical needs of ethnic minorities and religious denominations and groups.

\section{Discussion}

The above analysis of education systems reveals that the six criteria that we had developed can indeed serve as an instrument for determining the extent to which a national education system provides for the needs and requirements of the ethnic and other minorities in a country. All the systems in our sample - and arguably most others - have to contend with problems of minorities of all sorts within their boundaries, and each system has, somehow, to provide (or choose not to provide) in and for the pedagogical needs of those minorities within the constraints of their financial abilities. The analysis also shows that political powers tend to accommodate minorities and their needs to various extents, and in a variety of configurations as dictated by local circumstances.

\section{Conclusion}

This exercise demonstrates that it would be extremely difficult if not totally impossible to draft the outline of an ideal system that would be able to accommodate all forms of diversity, including the demands, needs and requirements of ethnic minorities, optimally. We therefore recommend that policy makers and constructors of education systems strive towards complying with our criteria. They should firstly strive towards accommodating as far as possible all the individual and group differences in the population of their country. They should then also strive towards the promotion of a spirit of commonality and communality and, in doing so, towards national unity and nation building. They should furthermore apply themselves to the attainment of social justice, in the process respecting the equality and equivalence of all individuals and groups as well as the basic human rights of each and every citizen and the groups she or he belongs to. Finally, they should dedicate themselves to the task of providing in the pedagogical needs and requirements of each individual and community within the state, and should ensure that all their actions are fair and equitable. 
This research has set out to focus on the capacity of education systems in addressing the issue of ethnic diversity, and the article has clearly been written from the perspective of the scholarly field of Comparative Education, which distinguishes itself with its system perspective on education: the holistic study of the structure of education systems, the components and elements of the structure and the societyeducation system interrelationships (Wolhuter 2011:26-27). As soon as elements of the education system themselves becomes the focus of study, the realms of other scholarly fields of Education enters. Valuable follow-up research to the research reported in this study would be to focus on each of these elements, and to evaluate their capacity to address ethnic diversity, for example a study of Citizen Education programmes (by scholars in the field of Citizen Education) or the history of the exclusion of minorities from education (by scholars in the field of History of Education).

\section{Acknowledgements Competing interests}

The authors declare that they have no financial or personal relationships which may have inappropriately influenced them in writing this article.

\section{Authors' contributions}

The authors C.C.W. (North-West University), F.J.P. (NorthWest University) and J.L.v.d.W. (North-West University) contributed equally to the research and writing of this article.

\section{References}

Al-Haj, M., 2002, 'Multiculturalism in deeply divided societies: The Israeli case', International Journal of Intercultural Relations 26, 169-183.

Armesto, F.F., 2004, Ideas that changed the world, Dorling Kindersley, London.

Australian Institute of Aboriginal and Torres Strait Islander Studies (AIATSIS) \& Federation of Aboriginal and Torres Strait Islander Languages (FATSIL), 2005, National Indigenous Languages Survey Report 2005, Department of 2005, National Indigenous Languages Survey Report 2005, Department
Communications, Information Technology and the Arts (DCITA), Canberra.

Basave, A., 2006, Intergral philosophy of education: A new 'Padea', viewed 12 December 2011, from http://www.bu.edu/wcp/Papers/Educ/EducBasa.htm on 8.11.2006

Bekerman, Z., 2010, 'Israel: Unsuccessful and limited multicultural education', in C.C. Wolhuter \& H.J. Steyn (eds.), Education and Ethnicity: Comparative perspectives, pp. 100-118, Platinum Press, Potchefstroom.

Berkhout, S.J. \& Bondesio, M.J., 1987, 'Die mite en meriete van gelyke onderwysgeleenthede', Suid-Afrikaanse Tydskrif vir Opvoedkunde (6)1, 15-19.

Bowie, N.E., 1970, 'Equality and distributive justice', The Journal of the Royal Institute of Philosophy, pp. i-xx.

Caldwell, B.J., 2003, 'Mission impossible? A strategic view of efforts to lead the transformation of schools', University of Melbourne, Melbourne, from http:// www.edfact.unimelb.edu.au/dean/docs/ICP_Edinborough.pdf

Cambron-McCabe, N. \& McCarthy, M., 2004, 'Student discipline and access to equal educational opportunities in the United 'States', Perspectives in Education (22)3, 89-97.

Chipman, L., 1980, 'The menace of multiculturalism', Quadrant, September, 3-6.

Cohen, Y.A., 1970, 'Schools and civilization states', in J. Fischer (ed.), The social sciences and the comparative study of education, International Textbook Company, Scranton.

Cowan, L.G., O'Connell, J. \& Scanlon, D.G., 1965, Education and nation building in Africa, Frederick Prayer, London.

Dahan, Y. \& Levy, G., 2000, 'Multiculturalism education in the Zionist State - The Mizrahi Challenge', Studies in Philosophy and Education 19, 423-444.

Dowden, R., 2009, Africa: Altered states, ordinary miracles, Portobello, London.
Du Preez, M., 2009, Dwars mymeringe van 'n gebleikte Afrikaan, Zebra Drukkers, Kaapstad. Giddens, A., 1994, Beyond left and right: The future of radical politics, Polity, Cambridge. Indian Residential School Survivor's Society, 2009, Indian residential school history, viewed 01 April 2010, from http://www.irsss.ca/history.html

International Children's Summit, 1992, 'The Children's Charter of South Africa', paper presented at the International Conference on the Rights of Children in South Africa, University of the Western Cape, Bellville, 27 May - 01 June.

Isaac, T., 1995, Aboriginal law: Cases, materials, and commentary, Purich, Saskatoon. Jackson, R.J. \& Jackson, D., 2008, Comparative and world politics, Pearson/Prentice Hall, Toronto.

Jansen, J.D., 2009, Knowledge in the blood, Stanford University Press, Stanford.

Karvelas, N., 2006, 'Exploring the human rights understandings of educators', MEd dissertation, University of Pretoria, Pretoria.

Krüger, H-H. \& Helsper, W., 2006, Einführung in Grundbegriffe und Grundfragen der Erziehungswissenschaft, Barbara Budrich, Opladen.

Loo, S.P., 2008, 'The education system of Malaysia', in H.J. Steyn \& C.C. Wolhuter (eds.), Education Systems: Challenges of the 21st century, pp. 447-499, Keurkopie, Noordbrug.

Loo, S.P., 2010, 'Ethnicity and educational policies in Malaysia and Brunei Darussalam', in C.C. Wolhuter \& H.J. Steyn (eds.), Education and ethnicity: Comparative perspectives, pp. 119-137, Platinum Press, Potchefstroom.

Lucas, C.J., 1984, Foundations of education, Prentice Hall, Englewood Cliffs.

Ministry of Education (Israel), 2000, Statistics of the matriculation examination (Bagrut) 2000 Report, viewed 22 April 2010, from http://www.netvision.net.i./ bagrut/netumin2000htm

Ministry of Education (People's Republic of China), 2005, Introduction to ethnic minority education, viewed 06 April 2010, from http://www.moe.edu.cn/.edaas/ website 18/54/info12054.htm

Mncwabe, M.P., 1990, Separate and equal: South African education at the crossroads, Butterworth, Durban.

Nieuwenhuis, F.J., 2010, 'Social justice in education revisited', paper presented at the Örebro-UNISA International Conference, University of South Africa Muckleneuk Campus, Pretoria, South Africa, 01-03 February.

Nzabalirwa, W. 2010. 'Education et ethnicité au Ruanda: Perspective historique', in C.C. Wolhuter \& H.J. Steyn (eds), Education and ethnicity: Comparative perspectives, pp. 138-154, Platinum Press, Potchefstroom.

O'Neill, M., 2010, 'Forty years on: Education for a diverse Australia?' in C.C. Wolhuter \& H.J. Steyn (eds), Education and ethnicity: Comparative perspectives, pp. 33-57, Platinum Press, Potchefstroom.

Ottmann, J., 2010, 'Canada's first nations people: Ethnicity and leadership', in C.C. Wolhuter \& H.J. Steyn (eds), Education and ethnicity: Comparative perspectives, pp. 58-80, Platinum Press, Potchefstroom.

Pape, J., 1998, 'Changing education for majority rule in South Africa and Zimbabwe', Comparative Education Review 42(3), 253-266.

Pipes, R., 1972, 'National minorities sought autonomy and independence', in A.E. Adams (ed.), The Russian revolution and Bolshevik victory, pp. 110-123, D.C. Heath, Lexington.

Postiglione, G.A., 1999, 'Introduction: State schooling and ethnicity in China', in G.A. Postiglione (ed.), China's national minority education: Culture, schooling and development, pp. 3-19, Falmer Press, New York.

Potgieter, F.J. \& Van der Walt, J.L., 2008, Education Theory: Study Guide for EDCC 511 , Faculty of Education Sciences, Potchefstroom.

Pratt, R.L., 2000, Designed for dignity, P \& R Publishing, Phillipsburg.

Reid, W.A., 1999, Curriculum as institution and practice: Essays in the deliberative tradition, Erlbaum, Mahwah.

Reid, W.A., 2006, The pursuit of curriculum: Schooling and the public interest, Information Age, Greenwich, Cape Town.

Savinov, L.V. \& Kovaleva, M.I., 2010, 'Poly-ethnicity and a system of education in Russia with special reference to the Siberian Federal District', in C.C. Wolhuter \& H.J. Steyn (eds.), Education and ethnicity: Comparative perspectives, pp. 155-166, Platinum Press, Potchefstroom.

Sherman Swing, E., 2010, 'The multicultural dilemma: Studies from Europe and the USA', in V. Maseman, S. Majhanovic, N. Truong \& K. Janigan (eds.), A tribute to David N. Wilson: Clamouring for a better world, pp. 87-98, Sense Publishers, Rotterdam.

Shiraya, J., 2008, 'Knowledge of English is essential for kids' success', Cape Argus, 16 October, p. 18.

Soodyall, H., 2006, The prehistory of Africa, Jonathan Ball, Johannesburg.

Stanner, W.E.H., 1969, After the dreaming. The 1968 Boyer Lectures, Australian Broadcasting Commission, Sydney.

Thompson, A.R., 1981, Education and development in Africa, St Martin, New York.

Van Beek, U. (ed.), 2006, Democracy under construction. Patterns from four continents, Van Schaik, Pretoria.

Van der Walt, J.L., 2010, 'Ubuntu-waardes: Samelewings- en pedagogiese verwagtinge', Journal of Humanities 50(2), 229-242. 
Van Deventer, I., 2010, 'The nature of social justice', PhD thesis, Faculty of Education Sciences, Potchefstroom. (draft chapter of a forthcoming)

Waghid, Y., 2007, 'Teacher mobility: A loss to South African schools'?, Perspectives in Education 25(2), 101.

Welch, A.R., 1991, 'Knowledge and legitimation in Comparative Education', Comparative Education Review 35(3), 508-531.

Wielemans, W., 1993, Voorbij het individu, Garant, Apeldoorn.

Wolhuter, C.C., 1993, 'Gelyke onderwysgeleenthede met besondere verwysing na die implikasies daarvan vir onderwysvoorsiening in die R.S.A.', DEd thesis, University implikasies daarvan vir onder
of Stellenbosch, Stellenbosch.

Wolhuter, C.C., 1999, 'Sociaal-wetenschappelijke literatuur over onderwijs in ZuidAfrika: Van verzuiling tot eensgezindheid vanuit verscheidenheid', Pedagogische Studiën 76, 361-370.
Wolhuter, C.C., 2011, 'Comparative Education: Conceptual clarification of a field', in G. Likando, C.C. Wolhuter, K. Matengu \& J. Mushaandja (eds.), Comparative Education: An introduction, pp. 25-33, Keurkopie, Noordbrug.

Wolhuter, C.C., 2012, 'Godsdiens in onderwys in Suid-Afrika: Beligting vanuit internasionaal-vergelykende perspektiewe', Tydskrif vir Christelike Wetenskap 48(1\&2), 171-201.

World Bank, 2008, World Development Indicators, The World Bank, Washington DC.

Wright, R., 2009, The evolution of God, Little, Brown and Company, New York.

Yang, R. \& Wu, M., 2010, 'Education for ethnic minorities in China: A policy critique', in C.C. Wolhuter \& H.J. Steyn (eds.), Education and ethnicity: Comparative perspectives, pp. 81-99, Platinum Press, Potchefstroom. 